Article

\title{
Development of a Model Linking Physical Asset Management to Sustainability Performance: An Empirical Research
}

\author{
Damjan Maletič ${ }^{1}$, Matjaž Maletič ${ }^{1}$, Basim Al-Najjar ${ }^{2}$ and Boštjan Gomišček $^{3, * \mathbb{D}}$ \\ 1 Faculty of Organizational Sciences, University of Maribor, Kidričeva 55a, 4000 Kranj, Slovenia; \\ damjan.maletic@um.si (D.M.); matjaz.maletic@um.si (M.M.) \\ 2 Department of Mechanical Engineering, Faculty of Technology, Linnaeus University, \\ Building M, 35195 Växjö, Sweden; basim.al-najjar@lnu.se \\ 3 Faculty of Business, University of Wollongong in Dubai, Knowledge Park, Block 15, \\ P. O. Box 20183, Dubai, UAE \\ * Correspondence: BostjanGomiscek@uowdubai.ac.ae; Tel.: +971-4-278-1974
}

Received: 22 November 2018; Accepted: 11 December 2018; Published: 13 December 2018

check for updates

\begin{abstract}
This article is aimed at exploring the relationship between physical asset management (PAM) practices and sustainability performance. A framework of interrelated constructs was developed based on the existing literature and consequently tested through empirical study. Survey data were collected from organizations operating in six European countries (i.e., Greece, Poland, Slovakia, Slovenia, Sweden, and Turkey) and analyzed using Partial Least Squares Path Modeling (PLS-PM). The results offer support for the proposed hypotheses, showing that PAM practices positively influence the sustainability performance outcomes, namely economic, environmental, and employee-related social performance. Overall, this study demonstrates that a PAM framework can be conceptualized by four sub-constructs, namely physical asset risk management, physical asset performance assessment, physical asset lifecycle management, and physical asset policy and strategy. Finally, this study brings to light some theoretical and managerial implications as well as directions for future research. The findings of the study underscore PAM areas in which managers should focus on in order to optimize costs, performance, and risk exposures concerning the physical assets, and therefore enhance sustainability performance.
\end{abstract}

Keywords: physical asset management; ISO 55001; maintenance; sustainability performance; research model; SEM-PLS

\section{Introduction}

Organizations continuously search for new ways to improve performance and to get maximum return on their investments, i.e., physical assets. Indeed, appropriate management of physical assets is essential, especially in organizations where physical assets are the foundation for their success [1]. As such, over the last two decades, the demand for an effective physical asset management (PAM) has grown [2]. Since its advent, ISO 55000:2014 [3] and EN 16646:2014 [4] have also been important topics concerning the management of physical assets. Correspondingly, prior studies have emphasized the importance of taking a holistic view on managing physical assets [5].

The asset manager of today faces many challenges, such as the need to achieve sustainable development goals (i.e., social, economic, and environmental goals) [6], as well as the more conventional technical and economic goals. Furthermore, organizations should recognize the importance of risk management as well in order to use the best available technologies in the PAM 
process [7]. PAM has received considerable attention as having an important role in the management of the lifecycle of an asset as a whole, pursuing economic and physical performance, integrating risk measures, addressing the PAM within broader strategic and human perspectives, especially with the objective of improving both efficiency and effectiveness of resources [5]. An interdisciplinary approach should be applied in order to manage PAM effectively, particularly by bringing together traditional disciplines such as accounting, engineering, finance, humanities, logistics, and information systems technologies [1]. Our primary objective is to understand the performance implications of PAM utilization. This study draws on the assumption that PAM, which represents a systematic and structured process covering the whole lifecycle of physical assets (i.e., machinery and equipment), enhances sustainability performance. The concept of sustainability plays an important role in asset management. The reason for this lies in the fact that there exists a strong link between effective deployment of PAM and long-term sustainability-from the economic, environmental, and social point of view [3]. In support of this statement, it was evidenced in the literature (e.g., Valkokari et al. [8]; Lucato et al. [9]) that manufacturing has an enormous impact on all aspects of sustainable development.

Although PAM has recently been receiving considerable attention from researchers and practitioners, there is still a lack of research in this field. Therefore, while many studies have highlighted the importance of physical asset management, to the best of our knowledge none of the prior studies has explored the link between PAM and sustainability performance. As such, studies on PAM covering these aspects are rather limited. Most prior studies were devoted to defining the field of physical or engineering asset management (e.g., Amadi-Echendu et al. [5]), exploring the use of physical asset management practices in industry (e.g., Emmanouilidis and Komonen [10]), proposing models for managing the lifecycle of physical assets (e.g., Schuman and Brent [11]), or physical asset management implementation (e.g., Roda and Macchi [12]; Maletič [13]; Maletič et al. [14]). More recently, Alsyouf et al. [15] emphasized the necessity to identify and apply asset management key performance indicators to assess the impact of ISO 55000:2014 on organizational performance.

As such, it is pertinent to note that while literature provides a lot of theoretical evidence to support the argument that an organization can benefit from PAM practices, there is still lack of empirical support for this notion. Although studies (e.g., Alsyouf et al. [15]) such as those explained above imply that the effective management of assets plays an increasingly important role in improving performance outcomes, there is still a lack of empirical evidence to support this, especially with regard to the sustainability performance. Therefore, we intend to contribute to the literature by empirically verifying the mechanisms through which PAM can contribute to the sustainability performance.

In responding to this research gap, this paper develops a research framework and provides empirical evidence supporting the relationship between PAM and sustainability performance. The remainder of the paper is organized as follows: First, we develop hypotheses concerning the relationships between PAM and sustainability performance. Second, we demonstrate the research methodology and the results of this study. Finally, we discuss the theoretical and practical implications of the study.

\section{Theoretical Background and Hypotheses Development}

Prior to discussing the literature review on the relationship between PAM practices and sustainability performance, it is necessary to highlight the theoretical underpinning that stems from the resource-based theory upon which the research model is built on. During the last two decades, much research has been carried out to identify new competitive drivers and issues that are of significance for the performance outcome [16]. The concept of competitive advantage has been an extensively researched area in the management literature. For instance, Porter [17] postulates two types of competitive advantage, namely cost leadership and differentiation. Furthermore, different theories have been proposed in this field. One of them is the resource-based theory (RBT) [18]. The RBT has also recently received attention in the field of PAM [16]. As pointed out by Al-Najjar [19], a company should use its valuable and rare resources efficiently and effectively to achieve performance excellence. 


\subsection{Physical Asset Management Policy and Strategy}

PAM considers the entire lifecycle of an asset, from its design to its final disposal. As indicated by ISO 55001:2014 [3], top management should establish an asset management policy to provide the framework for setting asset management objectives and to continuously improve the asset management system. The asset management system supports an organization to manage the risks and costs of the assets, in a structured, efficient manner that supports continual improvement and ongoing value creation [3]. As such, these holistic views of asset management reflect the general movement in engineering circles to emphasize the importance of physical asset management rather than just asset maintenance to focus on the bigger picture of lifecycle asset assessment, including strategy, risk measurement, safety, and environmental and human factors [3]. As argued by Komonen et al. [20], asset management should be a part of the overall strategic management. Authors also emphasized that asset strategy is essential in order to manage physical assets over their lifecycle, taking into account different internal and external factors (e.g., technology, market). As evident in ISO 55001:2014 [3], asset management policy, objectives, and a strategic asset management plan (SAMP) are essential elements of an asset management system. In order to gain benefits, an asset management system should support the integration of asset management processes with other functions (e.g., quality, safety, risk, etc.). Based on the above arguments, it is plausible to postulate that the appropriate asset management policy, objectives, and strategy lead to better risk and lifecycle management of physical assets. Further, to develop an approach of measuring physical asset performance, it is imperative to have a well-formulated asset strategy. Accordingly, Parida [21] highlighted the importance of the linkage between business objectives and asset performance measurements. Hence, it is essential that activities within asset management systems including planning, implementing, monitoring, and review should be measured with appropriate performance indicators [22]. Therefore, on the basis of these arguments we hypothesize:

Hypothesis 1a. Physical asset management policy and strategy is positively related to physical asset risk management.

Hypothesis $\mathbf{1 b}$. Physical asset management policy and strategy is positively related to physical asset lifecycle management.

Hypothesis 1c. Physical asset management policy and strategy is positively related to physical asset performance assessment.

\subsection{Asset Risk Management}

Prior studies on risk management mainly explored enterprise risk management in relation to supply chain management (e.g., Wu and Olson [23]; Olson and Wu [24]). Several studies were focused on risk management form the ISO standards perspective (e.g., Chiarini [25]). However, effective risk management of industrial technologies is vital for organizations aiming to meet the requirements in different areas of organization management (e.g., occupational health and safety, accidents prevention, critical infrastructure, dangerous substances transportation, and environmental or financial requirements) [26]. This means that risk management is an important element of any asset management system. Hence, risk management is an inherent part of ISO 55001:2014 [3] as well. According to the standard, asset-management-related risks must be considered in the organization's overall risk management approach. The above discussion suggests that incorporating risk management into an organization's processes brings potential benefits with regard to managing physical assets. Accordingly, we hypothesize that:

Hypothesis 2. Physical asset risk management is positively related to physical asset lifecycle management. 


\subsection{Physical Asset Lifecycle Management}

It is widely recognized that physical asset management has an impact on various operational measures when considering different stages of an asset lifecycle. For example, Haider, et al. [27] argued that the design of an asset has a direct impact on its productivity, which is concerned with minimizing the disturbances such as unplanned failure. Therefore, performance benefits can be reflected in terms of creating and sustaining value during each phase of the asset lifecycle [28], as well as in achieving factors such as quality, cycle time, employee skills, and productivity [29]. In this regard, Schuman and Brent [11] provided a conceptual model for an asset lifecycle management to improve performance in the process industry. Authors indicated that aspects of corporate sustainability should be considered in asset lifecycle management. Furthermore, Labuschagne and Brent [30] highlighted the need to integrate an asset lifecycle approach to achieve environmental performance. Additionally, the authors emphasize the need to identify appropriate indicators to measure the impact of assets considering all the lifecycle phases. Moreover, Chen et al. [31] proposed the concept of asset maintenance business model innovation to form sustainable competitive advantages. Given that maintenance is one of the main elements of the asset lifecycle, this implies the positive link between asset lifecycle and environmental performance as one of the pillars of corporate sustainability. As such, we argue that with the proper management of physical assets through the entire lifecycle of organizations could benefit in terms of improving environmental performance. Therefore, we hypothesize that:

Hypothesis 3a. Physical asset lifecycle management is positively related to physical asset performance assessment.

Hypothesis 3b. Physical asset lifecycle management is positively related to environmental performance.

\subsection{Physical Asset Performance Assessment}

Considering the operations perspective, a business performance measurement system (PMS) is regarded as a set of metrics used to quantify the efficiency and effectiveness of actions [32]. It has been argued that more advanced approaches of PMSs have been proposed (e.g., Kaplan and Norton [33]), which include financial and non-financial performance measures, as well as explain cause-and-effect relationships between the various measures, and provide better insight in terms of links between PMS and an organization's strategy. In relation to manufacturing, prior research has largely investigated maintenance performance measurement (e.g., Muchiri, et al. [34]; Parida and Chattopadhyay [35]). Recently, the importance of performance measurement has also been highlighted in the field of asset management assessment [21,22]. Therefore, performance measurement is of key importance for improving the efficiency and effectiveness of physical asset handling processes [14]. Accordingly, several authors (e.g., Searcy [36]) have emphasized that the measuring, monitoring, and evaluating of sustainability performance (i.e., environmental, economic, and social performance) is crucial for its improvement. As indicated by Klassen [37], environmental management plays an essential role in the economic performance of the company. The authors explained that profitability could be affected by the higher production costs of environmental management initiatives. While environmental performance is a more understandable concept, social performance measurement remains an evolving debate in the literature [38]. However, employee-related social aspects (e.g., turnover, employee satisfaction, and motivation) have been vastly explored in the literature (e.g., Hancock et al. [39]; Harter et al. [40]; Ramlall [41]), especially in relation to the performance outcome of the company. As in any management system, an asset management system should provide a framework for establishing an appropriate leadership, clear defined goals and objectives, strategy, plans, commitment, and support for the organizational stability, etc. It has been shown that these elements influence social aspects, such as turnover, employee satisfaction, and motivation [42,43]. Based on the above arguments, the following hypotheses have been developed: 
Hypothesis 4a. Physical asset performance assessment is positively related to environmental performance.

Hypothesis $\mathbf{4 b}$. Physical asset performance assessment is positively related to employee-related social performance.

\subsection{Physical Asset Management and Sustainability Performance}

Sustainability performance appears to be one of the most influential concepts for managing modern businesses. Adopting a sustainability-oriented holistic view to the area of industrial assets is essential for successful business operations [44]. When transferring the notion of sustainability to the business level, it can be accordingly defined as meeting the needs of an organization's direct and indirect stakeholders without compromising its ability to meet the needs of future stakeholders [45]. In fact, sustainability is a broad and very challenging approach often conceptualized in terms of the "triple bottom line" (TBL) [46], which implies that organizations will create more value over the long run if they take into consideration environmental, social, and economic issues [45]. PAM is ultimately accountable to TBL in business reporting in terms of economic, environmental, and social responsibilities [28]. Several past studies (e.g., Garetti and Taisch [47]; Ratnayake and Markeset [48]) have reported that in the context of industrial assets, the impact on sustainability is substantial. Using PAM, sustainability could be achieved through effective management of short- and long-term performance and costs, allowing the organization to consistently meet or exceed the performance and social responsibility expectations to satisfy the needs of stakeholders [3]. As reported by Ratnayake and Markeset [48], ineffective PAM leads to serious health, safety, and environment (HSE) and financial consequences. Furthermore, it has been evidenced in prior studies (e.g., Duijm et al. [49]) that profitability increases by improving availability and accident prevention (preventing loss of production and loss of human or capital resources).

Nowadays, organizations are under rising pressure from their stakeholders to recognize the impact of exploiting assets on the sustainable performance over their lifecycle [50]. Several studies (e.g., Surroca et al. [51]; Endrikat et al. [52]) have provided evidence demonstrating that environmentally and socially responsible activities lead to enhanced economic performance.

We, therefore, build on a premise that the integration of environmental and social aspects into the PAM framework could benefit organizations in terms of economic performance. Therefore, we hypothesize:

Hypothesis 5. Environmental performance is positively related to economic performance.

Hypothesis 6. Employee-related social performance is positively related to economic performance.

\section{Sample and Data Collection}

A questionnaire survey was utilized as a data collection method [53]. Data used in this study were collected using a large-scale web-based survey conducted by five universities which participated in this international research project. Prior to collecting the data, a survey coordinator was appointed at each participating university, mainly to: (a) assess the content validity of the measurement instrument (i.e., questionnaire) and (b) coordinate the process of data collection.

The data used in this study were obtained from a project conducted by a team of international researchers. With respect to study design procedures, a survey instrument was mailed to target respondents, followed by a reminder, especially to increase the response rate. In administering the survey, a cover letter was sent to each organization with the request that the questionnaire should be completed by a manager who has major operations responsibility and is competent concerning the organization's PAM practices and estimating performance outcomes. The project collects data from a sample consisting of organizations from the production environment and those dealing with 
assets (e.g., mining, retail services). As such, these industries provide a good setting for research on PAM. The size of an organization was not restricted. Nevertheless, it should be emphasized that this study merges all countries into one sample to provide a cross-country comparison. The selection of organizations was made through the website and business registers, as well as through e-mail addresses obtained by each of the participating universities' contact databases. In total, 138 questionnaires were completed and thereby included in the analysis, yielding a $13 \%$ response rate. This sample size is considered acceptable given the sample size of studies on asset (e.g., Emmanouilidis and Komonen [10]) and maintenance (e.g., Simões, Gomes, and Yasin [54]) management. The questionnaire was responded to by organizations that were located in Slovenia (31.9\% of total respondents), Poland (34.1\%), Greece (16.7\%), Sweden (6.5\%), Turkey (5.8 \%), and Slovakia (5.1\%).

Regarding the number of employees (following the guidelines of the Statistical Office of the Republic of Slovenia), the greatest proportion of organizations that responded were medium-sized organizations (51-250 employees) (31.3\%), followed by organizations employing 251-500 employees (21.7\%), small-sized organizations employing 50 or less employees $(17.4 \%)$, micro-enterprises having five or fewer employees (12.2\%), and organizations employing more than 500 employees (12.2\%).

Table 1 illustrates the sample profile based on Slovenian Standard Industrial Classification Codes (SIC). According to the results, the majority of responses to the survey were from the manufacturing industry $(39.3 \%)$.

Table 1. Sample distribution by industry type.

\begin{tabular}{lc}
\hline \multicolumn{1}{c}{ Industry (Standard Industrial Classification) } & Share (\%) \\
\hline Agriculture, Forestry, and Fishing & 1.7 \\
Mining and Quarrying & 6 \\
Manufacturing & 39.3 \\
Electricity, Gas, Steam, and Air Conditioning Supply & 2.6 \\
Water Supply, Sewerage, Waste Management, and Remediation Activities & 0.9 \\
Construction & 6.8 \\
Wholesale and Retail Trade, Repair of Motor Vehicles and Motorcycles & 16.2 \\
Transportation and Storage & 5.1 \\
Accommodation and Food Service Activities & 0.9 \\
Information and Communication & 3.4 \\
Financial and Insurance Activities & 0.9 \\
Other & 16.2 \\
Total & 100 \\
\hline
\end{tabular}

\subsection{Measures}

The instrument used in the present study consists of two major parts. The first part comprises four sub-constructs measuring PAM, and the second part comprises three sub-constructs measuring sustainability performance. The scales items used in this research are developed based on a comprehensive literature review. In order to assure consistency between the construct and its conceptualization, experts reviewed all items. Experts give suggestions to improve, drop, or keep the items. They also offered suggestions to add additional items as well. Prior to the survey mail out, the questionnaire was tested in a company form asset-intensive industry, particularly to obtain feedback regarding the clarity of the questions. Items for measuring PAM and sustainability performance are presented in Appendices A and B.

\subsubsection{Physical Asset Management Construct}

The main themes used to describe PAM in this study are in compliance with the ISO 55001:2014 [3] standard. It is deemed necessary to emphasize that the PAM construct was designed to capture all the main aspects of an asset management system. As mentioned above, four sub-constructs for measuring PAM are used in this study, namely PAM policy and strategy, physical asset risk management, 
physical asset lifecycle management, and physical asset performance assessment. Items for measuring these sub-constructs were derived from past studies on PAM $[10,13,55]$ and quality management $[56,57]$. The scale of physical asset risk management incorporated six items assessing the use of risk assessment and the analysis of the relevant working areas. It is the requirement of the ISO 55001:2014 [3] that asset-related risk should be addressed. The physical asset performance assessment scale includes nine items measuring activities for monitoring and analyzing data related to asset management activities. As such, we have focused on all relevant asset information. The scale of physical asset lifecycle management comprises six items assessing activities for managing assets through the entire lifecycle. The importance of this aspect has been well-noted in the literature on PAM [11]. Lastly, PAM policy and strategy incorporated four items assessing top management activities. In accordance with ISO 55001 [3], a SAMP (often referred as an asset management strategy) is documented information that specifies how organizational objectives are converted to asset management objectives, addresses the approach for developing asset management plans, and defines the role of the asset management system. We capture these elements with the measures used in the aforementioned sub-construct.

\subsubsection{Sustainability Performance Construct}

The sustainability performance was operationalized with three dimensions covering the aspect of the TBL. Items for each sub-construct were identified based on a comprehensive literature review [42,43,58-61]. The effect of PAM deployment should trigger benefits in terms of performance outcome. As mentioned previously, the main purpose of the ISO 55001 [3] standards is to provide guidelines for organizations for building sound asset management systems to manage the risks and costs associated with assets and to realize the value of an organization's assets. Accordingly, several previous studies (e.g., Ratnayake [50]) emphasize that asset management supports the realization of value considering financial, environmental, and social aspects. The sustainability performance construct measures these elements. First, the scale comprised of five items reflecting dimensions of economic performance: return on investment (ROI), return on assets (ROA), sales growth, profit growth, and market share. Second, the scale of an item's environmental performance includes three items measuring resource consumption, the percentage of recycled materials, and waste ration. Third, the scale of employee-related social performance is comprised of three items measuring turnover ratio, employees' satisfaction, and employee's motivation. The social performance construct was operationalized from the perspective of the employees rather than to measure it in general, wide-ranging terms of the social sustainability aspect.

\section{Analyses and Results}

\subsection{Common Method Variance}

Considering that the data for both the independent and dependent variables were collected from a single respondent, one can argue that common method variance might be a potential problem [62]. In this respect, we utilized Harman's single-factor test by performing exploratory factor analysis (unrotated principal factor analysis) on all of the measured variables. According to the results, the total variance for a single factor is $37.9 \%$. Owing to the fact that the total variance is less than $50 \%$, it is advocated that common method variance is not an issue in our dataset.

\subsection{Measurement Model Assessment}

In order to assess both the measurement and structural models we utilized the Partial Least Squares Path Modeling (PLS-PM) using the R package, plspm [63]. PLS-PM can be considered as a method for analyzing multiple relationships between blocks of variables. Generally, a model that is examined by the PLS-PM method constitutes of two sub-models; the structural model also known as the inner model and the measurement model also known as the outer model. According to the Chin and Newsted [64], this technique is applicable even under conditions of small sample sizes. 
Several analyses were performed to verify the suitability of the measurement model in terms of reliability, convergent validity, and discriminant validity [65]. Considering the PLS-PM measurement model (outer model) assessment, loadings and communalities were checked. Fundamentally, loadings are considered as the correlations between a latent variable and its indicators. Furthermore, communalities are represented by squared correlations, which measure the part of the variance between a latent variable and its indicator [63]. The recommended threshold value for loadings is 0.7 [63]. The outer model assessment results (loadings, weights, and communalities) for studied constructs are presented in Appendices A and B. As evidenced by the results, the measurement model is suitable, concerning the loading threshold criterion of 0.7 . Additionally, cross-loadings were also checked to identify potential traitor indicators [63].

The block unidimensionality was checked by the following indices: Cronbach's alpha, Dillon-Goldstein's rho, and eigenvalues, see Table 2. It should be noted that the purpose of the Cronbach's alpha is to evaluate how well a block of indicators measure their corresponding latent construct [56]. According to the results, the Cronbach's alpha values for each of the latent variables were above the suggested value of $0.70[63,65]$. Additionally, composite reliability was assessed by Dillon-Goldstein's rho. As suggested by Sanchez (2013), the value of this index should be 0.7 or above to consider the corresponding block as unidimensional. As shown by the results, Dillon-Goldstein's rho values for all the latent variables are above the recommended value of 0.7 . Furthermore, eigenvalues were checked to verify the unidimensionality. It is suggested [63] that the block is considered as unidimensional if the first eigenvalue is larger than 2.

Table 2. Summary of the results regarding the block unidimensionality.

\begin{tabular}{|c|c|c|c|c|c|c|}
\hline & Mode & MVs & Cronbach's Alpha & Dillon-Goldstein's rho & eig.1st & eig.2nd \\
\hline Physical asset management policy and Strategy (LV1) & A & 4 & 0.835 & 0.891 & 2.69 & 0.732 \\
\hline Physical asset risk management (LV2) & $\mathrm{A}$ & 6 & 0.920 & 0.937 & 4.29 & 0.523 \\
\hline Physical asset lifecycle management (LV3) & A & 6 & 0.856 & 0.893 & 3.49 & 0.627 \\
\hline Physical asset performance assessment (LV4) & A & 9 & 0.916 & 0.931 & 5.4 & 0.744 \\
\hline Environmental performance (LV5) & A & 3 & 0.681 & 0.825 & 1.84 & 0.729 \\
\hline Employee-related social performance (LV6) & A & 3 & 0.673 & 0.822 & 1.82 & 0.733 \\
\hline Economic performance (LV7) & A & 5 & 0.846 & 0.891 & 3.11 & 0.715 \\
\hline
\end{tabular}

(Notes. MVs-manifest variables (No. of items). A—reflective mode. eig.1st-first eigenvalue. eig.2nd-second eigenvalue.)

\subsection{Structural Model Assessment}

The results of the structural (inner) model assessment are summarized in Table 3, where the variance (R2) for endogenous latent variables is also presented. As shown by the results, $26.1 \%$ of the variance in the "economic performance (LV7) "is explained by independent variables (i.e., "physical asset lifecycle management (LV3)" and "physical asset performance assessment (LV4)"). Furthermore, results suggest that $29.7 \%$ of the variance in "environmental performance (LV5)" is explained by its independent variables. As observed by the results, the lower variance $(10.1 \%)$ in the "employee-related social performance (LV6)" in explained by the corresponding independent variables.

Moreover, average communality, illustrating the average of all the squared correlations between each manifest variable and the corresponding latent variable scores in the model [66] are presented in Table 3. According to the results, the highest value corresponds to the "physical asset risk management (LV2)", while the lowest value corresponds to the "physical asset lifecycle management (LV3)" and "physical asset performance assessment (LV4)". The mean redundancy, that is, the average of the redundancy indices of the endogenous blocks [63] is also shown in Table 3. High redundancy underlines the ability to predict; for example, "PAM policy and strategy (LV1)" predicts $35.62 \%$ of the variability of indicators of "physical asset risk management (LV2)" block. Furthermore, the Goodness of Fit (GoF) index could be calculated in terms of the geometric mean of the average communality index and the average R2 value [67]. According to the results generated by the plspm function, the GoF for our model is estimated to be 0.4761 . The main shortcoming of the GoF index is the fact that there is no threshold value that would essentially determine its statistical significance [63]. 
Table 3. Summary of the results regarding the inner model assessment.

\begin{tabular}{cccccc}
\hline & Type & R2 & Block Communality & Mean Redundancy & AVE \\
\hline Physical asset management policy and strategy (LV1) & Exogenous & 0.000 & 0.674 & 0.0000 & 0.674 \\
Physical asset risk management (LV2) & Endogenous & 0.499 & 0.714 & 0.3562 & 0.714 \\
Physical asset lifecycle management (LV3) & Endogenous & 0.503 & 0.581 & 0.3032 & 0.581 \\
Physical asset performance assessment (LV4) & Endogenous & 0.503 & 0.600 & 0.3199 & 0.600 \\
Environmental performance (LV5) & Endogenous & 0.297 & 0.612 & 0.1815 & 0.612 \\
Employee-related social performance (LV6) & Endogenous & 0.101 & 0.605 & 0.0609 & 0.605 \\
Economic performance (LV7) & Endogenous & 0.261 & 0.622 & 0.1627 \\
\hline
\end{tabular}

(Notes. AVE-Average Variance Extracted.)

Regarding the assessment of the validity of the structural model, the average variance extracted (AVE) was used, particularly, to measure the amount of variance that a latent variable captures from its indicators in relation to the amount of variance due to measurement error [63]. The results indicate that AVEs for latent variables are above the recommended threshold of 0.5 [63].

Path analysis is further illustrated by testing the relationships among latent variables. The assessment of structural model is performed by assessing the path coefficients, see Table 4 and Figure 1. According to the Sanchez [63], path coefficients represent the strength and direction of the relations between the latent variables. The research model proposed in this study suggests that there is a strong and positive link between "PAM policy and strategy (LV1)" and "physical asset risk management (LV2)" (0.706). Moreover, "PAM policy and strategy (LV1)" also positively and directly affects "physical asset lifecycle management (LV3)" (0.260) and "physical asset performance assessment (LV4)" (0.407). Furthermore, "physical asset lifecycle management (LV3)" appears to have a direct impact on "physical asset performance assessment (LV4)" (0.382) and "environmental performance (LV5)" (0.286). "physical asset performance assessment (LV4)" also predicts the performance results, namely it has an impact on "environmental performance (LV5)" (0.317) and "employee-related social performance (LV6)" (0.181).

Table 4. Path coefficients.

\begin{tabular}{|c|c|c|c|c|c|}
\hline Hypothesis & Path & Direct & Indirect & Total & $\mathbf{t}$ \\
\hline H1a & $\mathrm{LV} 1 \rightarrow \mathrm{LV} 2$ & 0.706 & 0.0000 & 0.7063 & $11.60 * *$ \\
\hline $\mathrm{H} 1 \mathrm{~b}$ & $\mathrm{LV} 1 \rightarrow \mathrm{LV} 3$ & 0.260 & 0.3543 & 0.6140 & $3.03^{* *}$ \\
\hline \multirow[t]{4}{*}{$\mathrm{H} 1 \mathrm{c}$} & LV1 $\rightarrow$ LV4 & 0.407 & 0.2347 & 0.6417 & $5.29 * *$ \\
\hline & LV1 $\rightarrow$ LV5 & 0.000 & 0.3788 & 0.3788 & \\
\hline & LV1 $\rightarrow$ LV6 & 0.000 & 0.2035 & 0.2035 & \\
\hline & $\mathrm{LV} 1 \rightarrow \mathrm{LV} 7$ & 0.000 & 0.2046 & 0.2046 & \\
\hline \multirow[t]{5}{*}{$\mathrm{H} 2$} & $\mathrm{LV} 2 \rightarrow \mathrm{LV} 3$ & 0.502 & 0.0000 & 0.5016 & $5.85^{* *}$ \\
\hline & $\mathrm{LV} 2 \rightarrow \mathrm{LV} 4$ & 0.000 & 0.1917 & 0.1917 & \\
\hline & $\mathrm{LV} 2 \rightarrow \mathrm{LV} 5$ & 0.000 & 0.2041 & 0.2041 & \\
\hline & $\mathrm{LV} 2 \rightarrow \mathrm{LV} 6$ & 0.000 & 0.0608 & 0.0608 & \\
\hline & $\mathrm{LV} 2 \rightarrow \mathrm{LV} 7$ & 0.000 & 0.1014 & 0.1014 & \\
\hline Н3а & LV3 $\rightarrow$ LV4 & 0.382 & 0.0000 & 0.3823 & $4.97 * *$ \\
\hline \multirow[t]{3}{*}{$\mathrm{H} 3 \mathrm{~b}$} & LV3 $\rightarrow$ LV5 & 0.286 & 0.1211 & 0.4069 & $3.07^{* *}$ \\
\hline & LV3 $\rightarrow$ LV6 & 0.000 & 0.1212 & 0.1212 & \\
\hline & $\mathrm{LV} 3 \rightarrow \mathrm{LV} 7$ & 0.000 & 0.2022 & 0.2022 & \\
\hline $\mathrm{H} 4 \mathrm{a}$ & LV4 $\rightarrow$ LV5 & 0.317 & 0.0000 & 0.3169 & $3.40 * *$ \\
\hline \multirow[t]{2}{*}{$\mathrm{H} 4 \mathrm{~b}$} & $\mathrm{LV} 4 \rightarrow \mathrm{LV} 6$ & 0.317 & 0.0000 & 0.3171 & $3.90 * *$ \\
\hline & $\mathrm{LV} 4 \rightarrow \mathrm{LV7}$ & 0.000 & 0.1977 & 0.1977 & \\
\hline H5 & LV5 $\rightarrow$ LV7 & 0.443 & 0.0000 & 0.4431 & $5.87^{* *}$ \\
\hline H6 & LV6 $\rightarrow$ LV7 & 0.181 & 0.0000 & 0.1806 & 2.39 * \\
\hline
\end{tabular}

(Notes. ${ }^{* *}$ statistically significant at the 0.01 level. * statistically significant at the 0.05 level).

Given the indirect effect, it can be observed that "PAM policy and strategy (LV1)" indirectly through "physical asset risk management (LV2)", "physical asset lifecycle management (LV3)", and "physical asset performance assessment (LV4)" influences the "environmental performance (LV5)" (0.3788) and "employee-related social performance (LV6)" (0.2035). Subsequently, it can be observed 
that "PAM policy and strategy (LV1)" also affects "Economic performance (LV7)" indirectly via the above mentioned latent variables (0.2046).

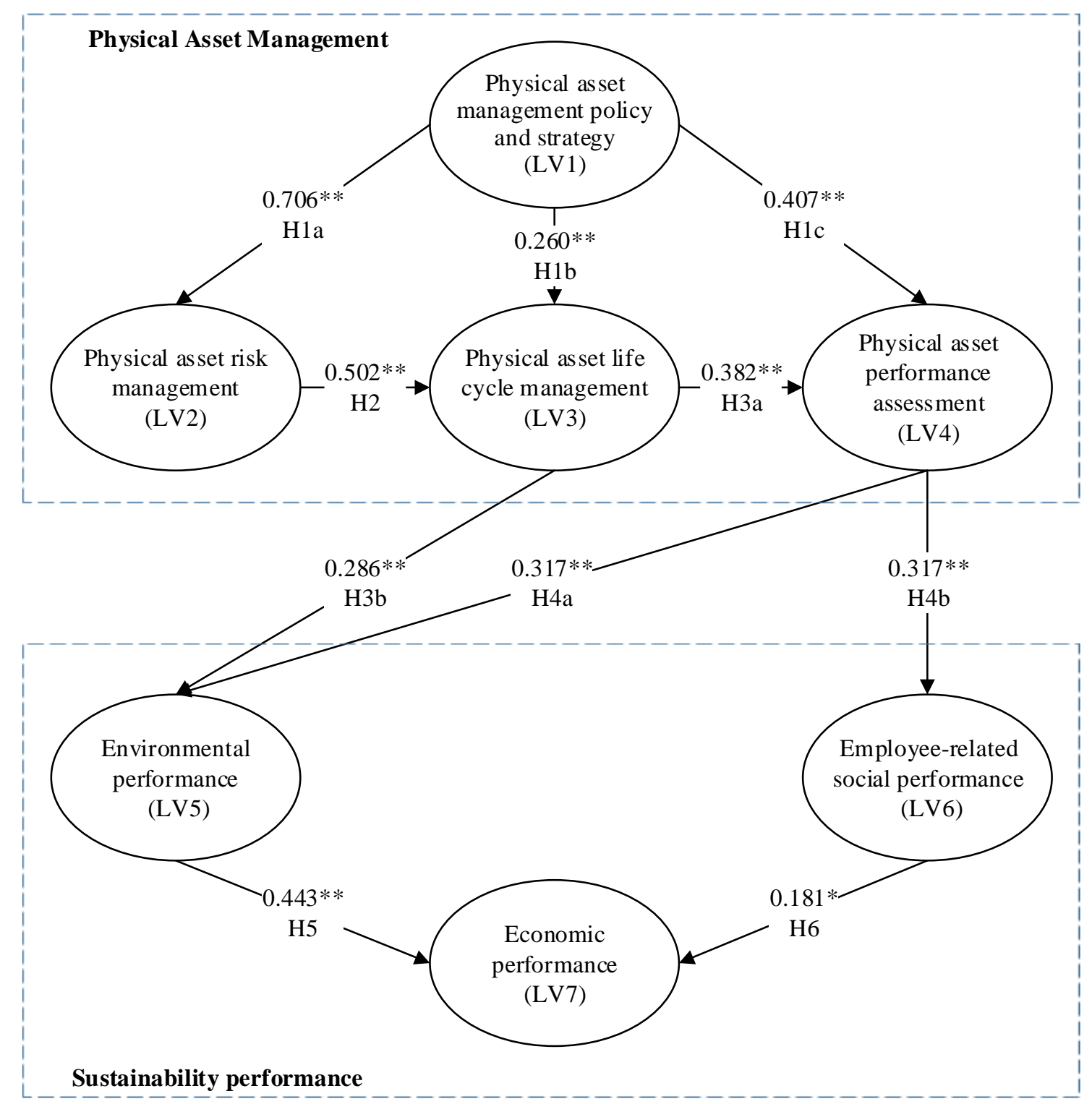

Figure 1. Structural (inner) model with path coefficients. (Notes. ${ }^{* *}$ statistically significant at the 0.01 level. * ${ }^{*}$ statistically significant at the 0.05 level).

Furthermore, a bootstrapping technique (1000 re-samples) was utilized to generate parameters' estimates that enable the evaluation of the statistical significance for the relationships hypothesized within the structural model $[63,68]$. The results of the bootstrap validation of the structural model are shown in Table 5. 
Table 5. Results of bootstrap validation of the structural model.

\begin{tabular}{ccccccc}
\hline Hypothesis & Path & $\begin{array}{c}\text { Original Path } \\
\text { (Total Effect) }\end{array}$ & $\begin{array}{c}\text { Mean } \\
\text { Boot }\end{array}$ & Std. Error & perc.025 & perc.975 \\
\hline H1a & LV1 $\rightarrow$ LV2 & 0.7063 & 0.7085 & 0.0510 & 0.5996 & 0.7958 \\
H1b & LV1 $\rightarrow$ LV3 & 0.6140 & 0.6167 & 0.0567 & 0.4993 & 0.7114 \\
H1c & LV1 $\rightarrow$ LV4 & 0.6417 & 0.6430 & 0.0494 & 0.5396 & 0.7324 \\
& LV1 $\rightarrow$ LV5 & 0.3788 & 0.3829 & 0.0615 & 0.2562 & 0.4963 \\
& LV1 $\rightarrow$ LV6 & 0.2035 & 0.2107 & 0.0529 & 0.1128 & 0.3115 \\
& LV1 $\rightarrow$ LV7 & 0.2046 & 0.2111 & 0.0405 & 0.1346 & 0.2915 \\
H2 & LV2 $\rightarrow$ LV3 & 0.5016 & 0.5012 & 0.0768 & 0.3385 & 0.6417 \\
& LV2 $\rightarrow$ LV4 & 0.1917 & 0.1912 & 0.0470 & 0.1018 & 0.2873 \\
& LV2 $\rightarrow$ LV5 & 0.2041 & 0.2023 & 0.0463 & 0.1168 & 0.2955 \\
& LV2 $\rightarrow$ LV6 & 0.0608 & 0.0627 & 0.0219 & 0.0258 & 0.1097 \\
H3a & LV2 $\rightarrow$ LV7 & 0.1014 & 0.1019 & 0.0255 & 0.0580 & 0.1563 \\
H3b & LV3 $\rightarrow$ LV4 & 0.3823 & 0.3829 & 0.0799 & 0.2313 & 0.5365 \\
& LV3 $\rightarrow$ LV5 & 0.4069 & 0.4078 & 0.0874 & 0.2327 & 0.5670 \\
& LV3 $\rightarrow$ LV6 & 0.1212 & 0.1259 & 0.0412 & 0.0534 & 0.2110 \\
H4a & LV3 $\rightarrow$ LV7 & 0.2022 & 0.2053 & 0.0491 & 0.1142 & 0.3052 \\
H4b & LV4 $\rightarrow$ LV5 & 0.3169 & 0.3178 & 0.1181 & 0.0773 & 0.5348 \\
& LV4 $\rightarrow$ LV6 & 0.3171 & 0.3277 & 0.0781 & 0.1705 & 0.4767 \\
H5 & LV4 $\rightarrow$ LV7 & 0.1977 & 0.2056 & 0.0633 & 0.0888 & 0.3271 \\
H6 & LV5 $\rightarrow$ LV7 & 0.4431 & 0.4421 & 0.0708 & 0.2969 & 0.5750 \\
\hline
\end{tabular}

As shown in Table 5, bootstrap intervals for all the path coefficients are non-zero. Hence, our empirical results indicate that the structural model has an acceptable prediction and that all hypothesized effects are positive and significant.

\subsection{Control Variable-Size}

Analysis of variance (ANOVA) was applied to examine whether company size matters when explaining to what extent organizations deploy PAM practices. The ANOVA test results, see Table 6, show a significant difference in the company size in terms of "physical asset risk management" (ANOVA statistic F(4.042), $p<0.05$ ), "physical asset performance assessment" (ANOVA statistic $\mathrm{F}(4.736), p<0.01$ ), "physical asset lifecycle management" (ANOVA statistic $\mathrm{F}(3.775), p<0.05$ ), and "physical asset management policy and strategy" (ANOVA statistic F(3.672), $p<0.05$ ).

Table 6. Analysis of variance (ANOVA)—Summary of the results.

\begin{tabular}{|c|c|c|c|c|c|c|}
\hline & Number of Employees & $\mathbf{N}$ & $\mathbf{M}$ & SD & SE & $\mathbf{F}$ \\
\hline \multirow{4}{*}{ Physical asset risk management } & $6-50$ & 20 & 3.5083 & 1.01231 & 0.22636 & \multirow{4}{*}{4.042 * } \\
\hline & $51-250$ & 36 & 3.5370 & 0.68558 & 0.11426 & \\
\hline & $251-500$ & 25 & 3.8067 & 0.72597 & 0.14519 & \\
\hline & above 500 & 14 & 4.3095 & 0.62654 & 0.16745 & \\
\hline \multirow{4}{*}{$\begin{array}{l}\text { Physical asset } \\
\text { performance assessment }\end{array}$} & $6-50$ & 20 & 3.0333 & 0.84627 & 0.18923 & \multirow{4}{*}{$4.736^{* *}$} \\
\hline & $51-250$ & 34 & 3.3889 & 0.82027 & 0.14067 & \\
\hline & $251-500$ & 25 & 3.6444 & 0.93404 & 0.18681 & \\
\hline & above 500 & 14 & 4.0873 & 0.71103 & 0.19003 & \\
\hline \multirow{4}{*}{$\begin{array}{c}\text { Physical asset } \\
\text { lifecycle management }\end{array}$} & $6-50$ & 20 & 3.4400 & 0.93268 & 0.20855 & \multirow{4}{*}{3.775 * } \\
\hline & $51-250$ & 34 & 3.8412 & 0.62237 & 0.10674 & \\
\hline & $251-500$ & 25 & 3.7840 & 0.75260 & 0.15052 & \\
\hline & above 500 & 14 & 4.2857 & 0.54752 & 0.14633 & \\
\hline \multirow{4}{*}{$\begin{array}{l}\text { Physical asset management } \\
\text { policy and strategy }\end{array}$} & $6-50$ & 20 & 3.3000 & 0.99538 & 0.22257 & \multirow{4}{*}{$3.672 *$} \\
\hline & $51-250$ & 36 & 3.5139 & 0.70949 & 0.11825 & \\
\hline & $251-500$ & 25 & 3.8200 & 0.73072 & 0.14614 & \\
\hline & above 500 & 14 & 4.0893 & 0.59329 & 0.15856 & \\
\hline
\end{tabular}

(Notes. ${ }^{* *}$ statistically significant at the 0.01 level. ${ }^{*}$ statistically significant at the 0.05 level. $\mathrm{N}=$ sample size;

$\mathrm{M}=$ mean; $\mathrm{SD}=$ Standard Deviation; $\mathrm{SE}=$ Standard Error of the Mean.) 
The Games-Howell post hoc testing revealed a significant difference between large companies (above 500 employees) and medium-sized companies (51-250 employees) and small companies (6-50 employees).

\section{Discussion}

The findings provide a number of insights into PAM. Although there has been a growing amount of literature focused on PAM, little empirical evidence regarding the impact of PAM practices on the sustainability performance has been presented. The subject is of great importance, especially if we consider that PAM could contribute to gaining a competitive advantage [20].

This research investigates the relationship between PAM practices (consists of four sub-constructs, namely physical asset management policy and strategy, physical asset risk management, physical asset lifecycle management, and physical asset performance assessment) and sustainability performance. More specifically, our research investigates the impact of PAM practices on environmental, social, and economic performance. Accordingly, our results show that PAM has a significant relationship with environmental, social, and economic performance. Therefore, the results of this research lend strong support for the hypotheses and show that organizations can benefit from the implementation of PAM practices. The findings of this research are in line with the research stream supporting the notion that PAM contributes to a company's performance $[5,10,11,13,15,20,28,40,48]$, characterized by sustainability performance. Further, the result shows that the size of an organization has an influence on the perceived dimensions of the PAM practices. Considering the statements describing the distinct PAM practices, it gives a clear indication that larger organizations are more aware of the importance of developing, implementing, maintaining, monitoring, analyzing, and improving asset management practices in order to support higher overall performance. It can be further explained because large companies that operate in an asset-intensive industry are more prompt in searching the ways to improve asset performance [11].

By and large, a proper SAMP represents an approach for organizations to implement asset management principles [3] which are defined in asset management policy [69,70]. SAMP, asset management policy, objectives, and plans form the asset management system, which can build a solid base for organizations seeking to improve their performance [13]. Our results support this by providing empirical evidence of a positive relationship between physical asset management policy and strategy with other elements of physical asset management construct. Indeed, our findings indicate that by establishing the right SAMP, companies could benefit in terms of costs, performance, and risk concerning their physical assets. Indeed, a recent study of Alsyouf et al. [15] showed that companies implementing an asset management system could achieve these benefits.

Further, our results are consistent with studies arguing that risk management is an essential element in managing industrial assets $[5,16]$. In conjunction with the aforementioned statement, the positive relationship between physical asset risk management and physical asset lifecycle management supports prior studies arguing that risk management is an effective tool in the decision-making process [71]. Indeed, our findings show that adopting PAM practices requirements in relation to risk issues can be addressed in a much better manner, which is also an essential role of an asset management system [3].

Many authors (e.g., Schuman and Brent [11]; Komonen et al. [20]) also stressed the importance of asset lifecycle management as a relevant task in asset management. Our findings support the view of these authors by providing empirical evidence pointing to the importance of asset lifecycle management in pursuing the performance benefits. In this regard, results are in line with prior studies (e.g., Labuschagne and Brent [30]) which indicated that asset lifecycle management supports organizations in their quest to achieve a higher sustainability performance. A more recent study by Ihemegbulem et al. [72] even indicated that effectively managing assets over their entire lifecycle phases is crucial in order to meet service delivery demands.

Moreover, our results support the conclusion of prior studies (e.g., Parida [16]; Ratnayake and Markeset [48]) that performance assessment is key for effective decision-making. Accordingly, our results 
showed that the monitoring and evaluation is a process that helps to improve performance and achieve the desired results. In support, Epstein [73] indicated that corporate social and environmental expenditures are increasing rapidly and the need to identify and manage these impacts has become critical. As such, our results regarding the link between physical asset performance assessment and performance output (in terms of social and environmental benefits) prove that companies implementing PAM practices should expect higher performance. As such, an asset management system supports an organization in their quest to manage environmental and social risks.

Finally, yet importantly, our model may provide plausible explanations for the wide range of results found in the literature regarding the relationship between environmental performance, social performance, and economic performance. Although we explored the performance benefits from the perspective of physical assets, our results nevertheless contribute to the literature suggesting environmental and social performance has a positive impact on its financial performance (e.g., Orlitzky et al. [38]; Nakao et al. [74]).

\subsection{Implications for Theory}

This research contributes to the literature on RBT by developing a better understanding of the relationship between PAM practices and sustainability performance. Our results presented empirical evidence that companies can benefit from PAM in terms of better performance outcome. As such, this paper makes important contributions by developing a theoretical framework and providing empirical results that contribute to the academic research, as well as providing practical insights for managers in the field of asset and maintenance management.

The key theoretical implication of the paper is the development of an empirically based framework for analyzing the relationship between PAM practices and sustainability performance. As such, this research presents the first attempt to empirically test the relationship between PAM practices and sustainability performance. Thus, this research significantly contributes to the literature on PAM.

Moreover, this research provides a valid and reliable set of measures for operationalizing PAM. A set of practices for managing assets effectively over the different stages of their lifecycle taking into account economic as well as performance and risk measures are proposed. Therefore, the present research provides empirical evidence to support the underlying factor structure of the PAM practices identified in the literature. As such, our analysis shows that the dimensions proposed by EFNMS-EAMC [55] fit this research dataset fairly well. The development of the scales for measuring PAM is deemed important for the further development of PAM research.

\subsection{Implications for Practice}

From a practical perspective, this research has several managerial implications. Despite the increasing popularity of PAM, the role of PAM practices in achieving better sustainability performance is still not sufficiently examined. In this regard, the theoretical arguments and empirical results confirm that companies pursuing PAM practices could meet their performance improvement expectations. Further, the empirical validation of the PAM construct recommends to managers which practices to focus on. As such, this research proposes a set of good practices related to risk management, performance assessment, lifecycle management, and practices concerning the development of PAM policy and strategy. It clearly indicates the areas in which managers should focus on in order to enhance sustainability performance. Another important point regarding PAM is that it affects all areas of the business (e.g., engineering, maintenance, safety, etc.). This is essential information for companies that want to adopt PAM and/or to be certified according to ISO 55001:2014 requirements. Finally, our research strongly emphasizes the need to recognize the role of PAM practices in achieving a key competitive edge.

\section{Conclusions}

This study presents empirical research, which examines the impact of PAM practices on sustainability performance. As such, our findings provide empirical evidence that PAM practices 
significantly and positively contribute to sustainability performance. Therefore, by and large, this research supports the positive argument concerning the applicability of PAM practices in asset-intensive industries. This research contributes to the literature by demonstrating the validity of the PAM construct and its relationship with sustainability performance.

As such, this paper presents a unique and novel contribution in the field of PAM. To the best of knowledge, this research is the first empirical test for examining the relationship between PAM practices and sustainability performance. It develops a valid and reliable set of measures for operationalizing PAM. Research on this will help researchers and practitioners to understand the role of PAM in achieving superior sustainability performance. In this regard, this study offers a solid foundation for further research on PAM.

\subsection{Future Research}

Although the research on PAM contributes to both academia and practice, we acknowledge several limitations that open-up avenues for further research. Considerable future research is necessary to replicate or extend the results presented in this research here. Therefore, future studies should revalidate the measurement scales. One limitation is that, although the measurement scales used in the paper are developed based on a comprehensive literature review, they capture only limited dimensions of PAM and performance outcomes. For example, social performance was limited to employee-related practices. Future studies could extend social performance scales and included external social impacts. Given the cross-sectional nature of the study, one should take caution in interpreting the causality between PAM practices and sustainability performance. As such, we see a compelling need for longitudinal studies that can improve the findings of this study, especially in capturing the dynamic change of PAM practices deployment and corresponding changes in performance outcomes. Further, apart from sustainability performance used in this research, future studies could explore the link between PAM and other aspects of performance (for instance exploring the impact of PAM on operational and quality performance). It has been widely accepted that production must follow sustainable development goals. In this regard, future studies could focus on the integration of sustainability aspects into PAM activities. Moreover, it should be recognized that there are possible sources of bias regarding the sample distribution. Indeed, sample characteristics determine the research settings and potentially affect both the internal and external validity of the study results [75]. Accordingly, future studies could utilize a stratified random sampling in order to improve the homogeneity of a sample. Furthermore, future studies could increase the generalizability of the results by considering additional methods through which the effect of the extraneous variables can be controlled.

\subsection{Concluding Remark}

This paper discusses the PAM construct and its link to the sustainability performance. The paper provides the research model for what we hope could further stimulate empirical research in the field of PAM and sustainable development. Accordingly, the developed constructs can be used in a variety of empirical research settings. We encourage researchers to build on the concept of PAM and further endeavor their efforts in explaining why some organizations gain more benefits than others from being engaged in PAM practices.

Author Contributions: D.M., M.M., B.A.-N. and B.G. carried out the research conceptualization and methodology design, from initial idea to model development. Application of statistical techniques was done by D.M. and M.M., B.G. supervised the research. B.A.-N. co-supervised the research. D.M. wrote the original draft version of the manuscript. M.M. and B.G. reviewed and edited the draft version.

Funding: This research received no external funding.

Acknowledgments: We would like to acknowledge the following individuals who contributed in many invaluable ways to the realization of the international survey: Assoc. Katerina Gotzamani and Maria Gianni (University of Macedonia, Greece), Assist. T. Bartosz Kalinowski (University of Lodz, Poland), Hana Pačaiová and Anna Nagyová (Technical University of Kosice, Slovakia), and Onur Altekin (Modeko Tekstil san. Ve Tic. Ltd. Sti., Turkey). 
Conflicts of Interest: The authors declare no conflict of interest.

\section{Appendix A}

Table A1. Questionnaire items and outer model assessment statistics for PAM practices.

\begin{tabular}{|c|c|c|c|c|}
\hline & Weight & Loading & Communality & Redundancy \\
\hline \multicolumn{5}{|l|}{ Physical asset management policy and strategy (LV1) } \\
\hline We apply asset management policy & 0.241 & 0.669 & 0.448 & 0.0000 \\
\hline We develop asset management objectives & 0.323 & 0.874 & 0.764 & 0.0000 \\
\hline We execute asset management strategy & 0.316 & 0.881 & 0.776 & 0.0000 \\
\hline $\begin{array}{l}\text { We undertake analyses of asset management policy to } \\
\text { determine future production capacity }\end{array}$ & 0.331 & 0.840 & 0.706 & 0.0000 \\
\hline \multicolumn{5}{|l|}{ Physical asset risk management (LV2) } \\
\hline $\begin{array}{l}\text { Risk management is an integrated part of asset } \\
\text { management strategy }\end{array}$ & 0.212 & 0.850 & 0.723 & 0.3607 \\
\hline $\begin{array}{l}\text { We perform risk assessment in order to minimize } \\
\text { business losses }\end{array}$ & 0.215 & 0.877 & 0.769 & 0.3835 \\
\hline $\begin{array}{l}\text { We embed risk into all activities which could affect } \\
\text { assets performance }\end{array}$ & 0.174 & 0.846 & 0.715 & 0.3567 \\
\hline $\begin{array}{l}\text { We analyze equipment failure causes and effects to } \\
\text { address risk }\end{array}$ & 0.202 & 0.838 & 0.703 & 0.3507 \\
\hline $\begin{array}{l}\text { We analyze operation, production, quality and logistic } \\
\text { process and address risk }\end{array}$ & 0.191 & 0.833 & 0.694 & 0.3461 \\
\hline $\begin{array}{l}\text { We analyze IT-system, business system, human } \\
\text { resources, competence, etc. and address risk }\end{array}$ & 0.189 & 0.825 & 0.680 & 0.3395 \\
\hline \multicolumn{5}{|l|}{ Physical asset lifecycle management (LV3) } \\
\hline $\begin{array}{l}\text { We evaluate capital expenditure requirements } \\
\text { considering whole lifecosts of ownership }\end{array}$ & 0.201 & 0.706 & 0.498 & 0.2600 \\
\hline $\begin{array}{l}\text { We assure quality of our assets during the whole } \\
\text { lifecycle phases }\end{array}$ & 0.226 & 0.768 & 0.589 & 0.3076 \\
\hline $\begin{array}{l}\text { We assure execution of maintenance processes within all } \\
\text { assets' lifecycle phases }\end{array}$ & 0.239 & 0.786 & 0.618 & 0.3224 \\
\hline $\begin{array}{l}\text { We continuously rationalize our assets to reduce } \\
\text { production cost }\end{array}$ & 0.177 & 0.730 & 0.533 & 0.2783 \\
\hline $\begin{array}{l}\text { We continuously modernize our assets in accordance } \\
\text { with our renewing/revision plans }\end{array}$ & 0.213 & 0.785 & 0.617 & 0.3219 \\
\hline $\begin{array}{l}\text { We execute disposal of assets in accordance with the } \\
\text { asset management plan }\end{array}$ & 0.252 & 0.794 & 0.630 & 0.3291 \\
\hline \multicolumn{5}{|l|}{ Physical asset performance assessment (LV4) } \\
\hline $\begin{array}{l}\text { We exploit information systems to support asset } \\
\text { management activities (ERP, CMMS, AMS, } \\
\text { or similar ones) }\end{array}$ & 0.127 & 0.654 & 0.427 & 0.2278 \\
\hline $\begin{array}{l}\text { Company collects and analyses data related to asset } \\
\text { management activities }\end{array}$ & 0.130 & 0.709 & 0.502 & 0.2676 \\
\hline We exploit asset history to enhance asset knowledge & 0.135 & 0.774 & 0.599 & 0.3191 \\
\hline $\begin{array}{l}\text { We undertake benchmarking to support asset } \\
\text { management activities }\end{array}$ & 0.143 & 0.788 & 0.621 & 0.3309 \\
\hline We monitor condition of critical assets & 0.167 & 0.801 & 0.641 & 0.3418 \\
\hline $\begin{array}{l}\text { We regularly review overall efficiency of asset } \\
\text { management activities }\end{array}$ & 0.141 & 0.793 & 0.630 & 0.3356 \\
\hline $\begin{array}{l}\text { We regularly review overall effectiveness of asset } \\
\text { management activities }\end{array}$ & 0.147 & 0.830 & 0.689 & 0.3675 \\
\hline $\begin{array}{l}\text { We monitor key performance indicators (KPIs) to verify } \\
\text { the achievement of organization's asset } \\
\text { management goals }\end{array}$ & 0.147 & 0.836 & 0.699 & 0.3728 \\
\hline $\begin{array}{l}\text { We proactively pursue continuous improvement of asset } \\
\text { management activities }\end{array}$ & 0.152 & 0.770 & 0.593 & 0.3162 \\
\hline
\end{tabular}




\section{Appendix B}

Table A2. Questionnaire items and outer model assessment statistics for sustainability performance dimensions.

\begin{tabular}{|c|c|c|c|c|}
\hline & Weight & Loading & Communality & Redundancy \\
\hline \multicolumn{5}{|l|}{ Environmental performance (LV5) } \\
\hline $\begin{array}{l}\text { Resource consumption (thermal energy, electricity, } \\
\text { water) has decreased (e.g., per unit of income, per unit of } \\
\text { production, etc.) during the last } 3 \text { years }\end{array}$ & 0.477 & 0.835 & 0.698 & 0.2053 \\
\hline $\begin{array}{l}\text { Percentage of recycled materials has increased during } \\
\text { the last } 3 \text { years }\end{array}$ & 0.452 & 0.838 & 0.703 & 0.2069 \\
\hline $\begin{array}{l}\text { Waste ratio (e.g., } \mathrm{kg} \text { per unit of product, } \mathrm{kg} \text { per } \\
\text { employee per year) has decreased during the last } 3 \text { years }\end{array}$ & 0.330 & 0.674 & 0.455 & 0.1339 \\
\hline \multicolumn{5}{|l|}{ Employee-related social performance (LV6) } \\
\hline Turnover ratio has decreased during the last 3 years & 0.425 & 0.683 & 0.466 & 0.0371 \\
\hline $\begin{array}{l}\text { Employees' satisfaction has increased during the last } \\
3 \text { years }\end{array}$ & 0.390 & 0.762 & 0.581 & 0.0462 \\
\hline $\begin{array}{l}\text { Employees' motivation has increased during the last } \\
3 \text { years }\end{array}$ & 0.495 & 0.834 & 0.695 & 0.0553 \\
\hline \multicolumn{5}{|l|}{ Economic performance (LV7) } \\
\hline $\begin{array}{l}\text { Return on investment (ROI) has increased above } \\
\text { industry average during the last } 3 \text { years }\end{array}$ & 0.254 & 0.704 & 0.495 & 0.0771 \\
\hline $\begin{array}{l}\text { Return on assets (ROA) has increased above industry } \\
\text { average during the last } 3 \text { years }\end{array}$ & 0.299 & 0.849 & 0.721 & 0.1122 \\
\hline $\begin{array}{l}\text { Sales growth has increased above industry average } \\
\text { during the last } 3 \text { years }\end{array}$ & 0.247 & 0.841 & 0.706 & 0.1100 \\
\hline $\begin{array}{l}\text { Profit growth rate has increased above industry average } \\
\text { during the last } 3 \text { years }\end{array}$ & 0.226 & 0.801 & 0.642 & 0.0999 \\
\hline Market share has increased during the last 3 years & 0.235 & 0.759 & 0.577 & 0.0898 \\
\hline
\end{tabular}

\section{References}

1. Frolov, V.; Lin, M.; Yong, S.; Wasana, B. Identifying Core Functions of Asset Management. In Definitions, Concepts and Scope of Engineering Asset Management; Amadi-Echendu, J.E., Brown, K., Willett, R., Mathew, J., Eds.; Springer: London, UK, 2010.

2. Wijnia, Y.; de Croon, J. The Asset Management Process Reference Model for Infrastructures. In 9th WCEAM Research Papers, 2014; Amadi-Echendu, J., Hoohlo, C., Mathew, J., Eds.; Springer: Cham, Switzerland, 2014.

3. ISO 55001:2014 Asset Management_Management Systems—Requirements; ISO: Geneva, Switzerland, 2014.

4. EN 16646:2014 Maintenance-Maintenance within Physical Asset Management; EN: Brussels, Belgium, 2014.

5. Amadi-Echendu, J.E.; Willett, R.J.; Brown, K.A.; Lee, J.; Mathew, J.; Vyas, N.; Yang, B.-S. What is engineering asset management? In Proceedings of the 2nd World Congress on Engineering Asset Management and the 4th International Conference on Condition Monitoring, Harrogate, UK, 11-14 June 2007.

6. Kishawy, H.; Hegab, H.; Saad, E. Design for Sustainable Manufacturing: Approach, Implementation, and Assessment. Sustainability 2018, 10, 3604. [CrossRef]

7. Thorpe, D. The development of strategic asset management leaders through postgraduate education. In Definitions, Concepts and Scope of Engineering Asset Management; Amadi-Echendu, J.E., Brown, K., Willett, R., Mathew, J., Eds.; Springer: London, UK, 2010.

8. Valkokari, K.; Valkokari, P.; Palomäki, K.; Uusitalo, T.; Reunanen, M.; Macchi, M.; Rana, P.; Prasanna Liyanage, J. Road-mapping the business potential of sustainability within the European manufacturing industry. Foresight 2014, 16, 360-384. [CrossRef]

9. Lucato, W.C.; Santos, J.C.D.S.; Pacchini, A.P.T. Measuring the Sustainability of a Manufacturing Process: A Conceptual Framework. Sustainability 2017, 10, 81. [CrossRef] 
10. Emmanouilidis, C.; Komonen, K. Physical asset management practices in industry: Comparisons between Greece and other EU countries. In Advances in Production Management Systems. Sustainable Production and Service Supply Chains; Prabhu, V., Taisch, M., Kiritsis, D., Eds.; Springer: New York, NY, USA, 2013.

11. Schuman, C.A.; Brent, A.C. Asset life cycle management: Towards improving physical asset performance in the process industry. Int. J. Oper. Prod. Manag. 2005, 25, 566-579. [CrossRef]

12. Roda, I.; Macchi, M. Studying the funding principles for integrating Asset Management in Operations: An empirical research in production companies. In Proceedings of the 3rd IFAC Workshop on Advanced Maintenance Engineering, Services and Technology AMEST 2016, Biarritz, France, 19-21 October 2016. [CrossRef]

13. Maletič, D. Interaction between Quality Management, Production and Maintenance Performance. Ph.D. Thesis, University of Maribor, Faculty of Organizational Sciences, Kranj, Slovenia, 2015.

14. Maletič, D.; Maletič, M.; Al-Najjar, B.; Gotzamani, K.; Gianni, M.; Kalinowski, T.B.; Gomišček, B. Contingency factors influencing implementation of physical asset management practices. Organizacija 2017, 50, 3-16. [CrossRef]

15. Alsyouf, I.; Alsuwaidi, M.; Hamdan, S.; Shamsuzzaman, M. Impact of ISO 55000 on organisational performance: Evidence from certified UAE firms. Total Qual. Manag. Bus. 2018, 1-19. [CrossRef]

16. Liyanage, J.P. Smart Engineering Assets through Strategic Integration: Seeing Beyond the Convention. In Asset Management: State of the Art in Europe from a Life Cycle Perspective; van der Lei, T., Herder, P., Wijnia, Y., Eds.; Springer: Dordrecht, The Netherlands, 2012.

17. Porter, M.E. Competitive Advantage: Creating and Sustaining Superior Performance; Free Press: New York, NY, USA, 1985.

18. Barney, J.; Ketchen, D.J.; Wright, M. The future of resource-based theory: Revitalization or decline? J. Manag. 2011, 37, 1299-1315. [CrossRef]

19. Al-Najjar, B. The lack of maintenance and not maintenance which costs: A model to describe and quantify the impact of vibration-based maintenance on company's business. Int. J. Prod. Econ. 2007, 107, 260-273. [CrossRef]

20. Komonen, K.; Kortelainen, H.; Räikkönen, M. Corporate Asset Management for Industrial Companies: An Integrated Business-Driven Approach. In Asset Management: State of the Art in Europe from a Life Cycle Perspective; van der Lei, T., Herder, P., Wijnia, Y., Eds.; Springer: Dordrecht, The Netherlands, 2012.

21. Parida, A. Asset performance measurement and management: Bridging the gap between failure and success. In Proceedings of the EuroMaintenance 2016, Athens, Greece, 30 May-1 June 2016.

22. Attwater, A.; Wang, J.Q.; Parlikad, A.; Russell, P. Measuring the performance of asset management systems. In Proceedings of the Asset Management Conference 2014, London, UK, 27-28 November 2014; pp. 1-6. [CrossRef]

23. Wu, D.D.; Olson, D. Enterprise risk management: A DEA VaR approach in vendor selection. Int. J. Prod. Res. 2010, 48, 4919-4932. [CrossRef]

24. Olson, D.L.; Dash Wu, D. A review of enterprise risk management in supply chain. Kybernetes 2010, 39, 694-706. [CrossRef]

25. Chiarini, A. Risk-based thinking according to ISO 9001: 2015 standard and the risk sources European manufacturing SMEs intend to manage. TQM J. 2017, 29, 310-323. [CrossRef]

26. Pačaiová, H. Machinery Safety Requirements as an Effective Tools for Operational Safety Management. In Risk Assessment; Svalova, V., Ed.; InTech: London, UK, 2018; ISBN 978-953-51-3799-3.

27. Haider, A.; Koronios, A.; Quirchmayr, G. You Cannot Manage What You Cannot Measure: An Information Systems Based Asset Management Perspective. In Proceedings of the Inaugural World Congress on Engineering Asset Management, Gold Coast, Australia, 11-14 July 2006; Mathew, J., Ma, L., Tan, A., Anderson, D., Eds.; Springer: London, UK, 2006.

28. Amadi-Echendu, J.E. Managing physical assets is a paradigm shift from maintenance. In Proceedings of the IEEE International Engineering Management Conference, Singapore, 18-21 October 2004. [CrossRef]

29. Bond, T.C. The role of performance measurement in continuous improvement. Int. J. Oper. Prod. Manag. 1999, 19, 1318-1334. [CrossRef]

30. Labuschagne, C.; Brent, A.C. Sustainable project life cycle management: The need to integrate life cycles in the manufacturing sector. Int. J. Proj. Manag. 2005, 23, 159-168. [CrossRef] 
31. Chen, J.; Zhang, R.; Wu, D. Equipment Maintenance Business Model Innovation for Sustainable Competitive Advantage in the Digitalization Context: Connotation, Types, and Measuring. Sustainability 2018, 10, 3970. [CrossRef]

32. Neely, A.; Gregory, M.; Platts, K. Performance measurement systems design: A literature review and research agenda. Int. J. Oper. Prod. Manag. 1995, 15, 80-116. [CrossRef]

33. Kaplan, R.S.; Norton, D.P. The Balanced Scorecard: Translating Strategy into Action; Harvard Business School Press: Boston, MA, USA, 1996.

34. Muchiri, P.; Pintelon, L.; Gelders, L.; Martin, H. Development of maintenance function performance measurement framework and indicators. Int. J. Prod. Econ. 2011, 131, 295-302. [CrossRef]

35. Parida, A.; Chattopadhyay, G. Development of a multi-criteria hierarchical framework for maintenance performance measurement (MPM). J. Qual. Maint. Eng. 2007, 13, 241-258. [CrossRef]

36. Searcy, C. Corporate sustainability performance measurement systems: A review and research agenda. J. Bus. Ethics 2012, 107, 239-253. [CrossRef]

37. Klassen, R.D.; McLaughlin, C.P. The impact of environmental management on firm performance. Manag. Sci. 1996, 42, 1199-1214. [CrossRef]

38. Orlitzky, M.; Schmidt, F.L.; Rynes, S.L. Corporate social and financial performance: A meta-analysis. Organ. Stud. 2003, 24, 403-441. [CrossRef]

39. Hancock, J.I.; Allen, D.G.; Bosco, F.A.; McDaniel, K.R.; Pierce, C.A. Meta-analytic review of employee turnover as a predictor of firm performance. J. Manag. 2013, 39, 573-603. [CrossRef]

40. Harter, J.K.; Schmidt, F.L.; Hayes, T.L. Business-unit-level relationship between employee satisfaction, employee engagement, and business outcomes: A meta-analysis. J. Appl. Psychol. 2002, 87, 268. [CrossRef] [PubMed]

41. Ramlall, S. A review of employee motivation theories and their implications for employee retention within organizations. J. Am. Acad. Bus. 2004, 5, 52-63.

42. Arthur, J.B. Effects of human resource systems on manufacturing performance and turnover. Acad. Manag. J. 1994, 37, 670-687.

43. Guthrie, J.P. High-involvement work practices, turnover, and productivity: Evidence from New Zealand. Acad. Manag. J. 2001, 44, 180-190.

44. Liyanage, J.P.; Badurdeen, F.; Chandima Ratnayake, R.M. Industrial Asset Maintenance and Sustainability Performance: Economical, Environmental, and Societal Implications. In Handbook of Maintenance Management and Engineering; Ben-Daya, M., Duffuaa, S.O., Raouf, A., Knezevic, J., Ait-Kadi, D., Eds.; Springer: London, UK, 2009.

45. Dyllick, T.; Hockerts, K. Beyond the business case for corporate sustainability. Bus. Strategy Environ. 2002, 11, 130-141. [CrossRef]

46. Elkington, J. Cannibals with Forks: The Triple Bottom Line of 21st Century Business; Capstone Publishing Ltd.: Oxford, UK, 1999.

47. Garetti, M.; Taisch, M. Sustainable manufacturing: Trends and research challenges. Prod. Plan. Control 2012, 23, 83-104. [CrossRef]

48. Ratnayake, R.M.C.; Markeset, T. Asset Integrity Management for Sustainable Industrial Operations: Measuring the Performance. Int. J. Sustain. Eng. 2012, 5, 145-158. [CrossRef]

49. Duijm, N.J.; Fiévez, C.; Gerbec, M.; Hauptmanns, U.; Konstandinidou, M. Management of health, safety and environment in process industry. Saf. Sci. 2008, 46, 908-920. [CrossRef]

50. Ratnayake, R.M.C. Sustainable Asset Performance: The Role of PAS $551 \& 2$ and Human Factors. Int. J. Sustain. Eng. 2013, 6, 198-211. [CrossRef]

51. Surroca, J.; Tribó, J.A.; Waddock, S. Corporate responsibility and financial performance: The role of intangible resources. Strateg. Manag. J. 2010, 31, 463-490. [CrossRef]

52. Endrikat, J.; Guenther, E.; Hoppe, H. Making sense of conflicting empirical findings: A meta-analytic review of the relationship between corporate environmental and financial performance. Eur. Manag. J. 2014, 32, 735-751. [CrossRef]

53. Kumar, R. Research Methodology: A Step-by-Step Guide for Beginners, 2nd ed.; Sage Publications Ltd.: London, UK, 2005. 
54. Simões, J.M.; Gomes, C.F.; Yasin, M.M. Changing role of maintenance in business organisations: Measurement versus strategic orientation. Int. J. Prod. Res. 2016, 54, 3329-3346. [CrossRef]

55. EFNMS-EAMC. How Organizations Manage Their Physical Assets in Practice, EFNMS Asset Management Survey (EFNMS). 2012. Available online: http://www.hms-gr.eu/t/files/ EAMCSurvey2011ReportFinal02122012.pdf (accessed on 2 April 2015).

56. Terziovski, M. Quality management practices and their relationship with customer satisfaction and productivity improvement. Manag. Res. News 2006, 29, 414-424. [CrossRef]

57. Lakhal, L.; Pasin, F.; Limam, M. Quality management practices and their impact on performance. Int. J. Qual. Reliab. Manag. 2006, 23, 625-646. [CrossRef]

58. Chang, D.S.; Kuo, L.C.R.; Chen, Y.T. Industrial changes in corporate sustainability performance-An empirical overview using data envelopment analysis. J. Clean. Prod. 2013, 56, 147-155. [CrossRef]

59. Fairfield, K.D.; Harmon, J.; Behson, S.J. Influences on the organizational implementation of sustainability: An integrative model. Organ. Manag. J. 2011, 8, 4-20. [CrossRef]

60. Maletič, M.; Maletič, D.; Dahlgaard, J.J.; Dahlgaard-Park, S.M.; Gomišček, B. Sustainability exploration and sustainability exploitation: From a literature review towards a conceptual framework. J. Clean. Prod. 2014, 79, 182-194. [CrossRef]

61. Maletič, M.; Maletič, D.; Dahlgaard, J.J.; Dahlgaard-Park, S.M.; Gomišček, B. Do corporate sustainability practices enhance organizational economic performance? Int. J. Qual. Serv. Sci. 2015, 7, 184-200. [CrossRef]

62. Podsakoff, P.M.; MacKenzie, S.B.; Jeong-Yeon, L.; Podsakoff, N.P. Common method biases in behavioral research: A critical review of the literature and recommended remedies. J. Appl. Psychol. 2003, 88, 879-903. [CrossRef]

63. Sanchez, G. PLS Path Modeling with R. Berkeley, Trowchez Editions ed. 2013. Available online: http://gastonsanchez.com/PLS_Path_Modeling_with_R.pdf (accessed on 15 April 2015).

64. Chin, W.W.; Newsted, P.R. Structural Equation Modeling Analysis with Small Samples Using Partial Least Squares; Hoyle, R.H., Ed.; Sage: Thousand Oaks, CA, USA, 1999; pp. 307-341.

65. Hair, J.F.; Black, W.C.; Babin, B.J.; Anderson, R.E. Multivariate Data Analysis, 7th ed.; Pearson Prentice Hall: London, UK, 2010.

66. Esposito Vinzi, V.; Trinchera, L.; Amato, S. PLS path modeling: From foundations to recent developments and open issues for model assessment and improvement. In Handbook of Partial Least Squares: Concepts, Methods and Applications; Esposito Vinzi, V., Chin, W.W., Henseler, J., Wang, H., Eds.; Springer: Berlin, Germany, 2010; pp. 47-82.

67. Tenenhaus, M.; Amato, S.; Vinzi, V.E. A global goodness-of-fit index for PLS structural equation modelling. In Proceedings of the XLII SIS Scientific Meeting, CLEUP, Padova, Italy, 9-11 June 2004; pp. 739-742.

68. Chin, W.W. The partial least squares approach to structural equation modeling. In Modern Methods for Business Research; Marcoulides, G.A., Ed.; Taylor \& Francis: Oxfordshire, UK, 1998; pp. 295-336.

69. Hastings, N.A.J. Physical Asset Management: With an Introduction to ISO55000; Springer: Cham, Switzerland, 2015.

70. Nateque Mahmood, M.; Prasad Dhakal, S.; Brown, K.; Keast, R.; Wiewiora, A. Asset management policies and guidelines of different states in Australia: A comparative analysis. J. Facil. Manag. 2014, 12, $286-302$. [CrossRef]

71. Pačaiová, H.; Sinay, J.; Nagyová, A. Development of GRAM-A risk measurement tool using risk based thinking principles. Measurement 2017, 100, 288-296. [CrossRef]

72. Ihemegbulem, I.; Baglee, D.; Wheatley, A.; Marttonen-Arola, S. The role of ISO 55000 Standard in asset integrity. In Proceedings of the 30th International Congress \& Exhibition on Condition Monitoring and Diagnostic Engineering Management Comadem, Preston, UK, 10-13 July 2017.

73. Epstein, M.J. Making Sustainability Work: Best Practices in Managing and Measuring Corporate Social, Environmental and Economic Impacts; Routledge: Oxfordshire, UK, 2018. 
74. Nakao, Y.; Amano, A.; Matsumura, K.; Genba, K.; Nakano, M. Relationship between environmental performance and financial performance: An empirical analysis of Japanese corporations. Bus. Strategy Environ. 2007, 16, 106-118. [CrossRef]

75. Harzing, A.W.; Reiche, B.S.; Pudelko, M. Challenges in International Survey Research: A review with illustrations and suggested solutions for best practice. Eur. J. Int. Manag. 2013, 7, 112-134. [CrossRef] 